\title{
NOTES ON THE BREEDING OF SOME LAMELLIBRANCHS FROM PLYMOUTH AND THEIR LARVAE
}

\author{
By Marie V. Lebour, D.Sc. \\ Naturalist at the Plymouth Laboratory
}

(Text-figs. I-7)

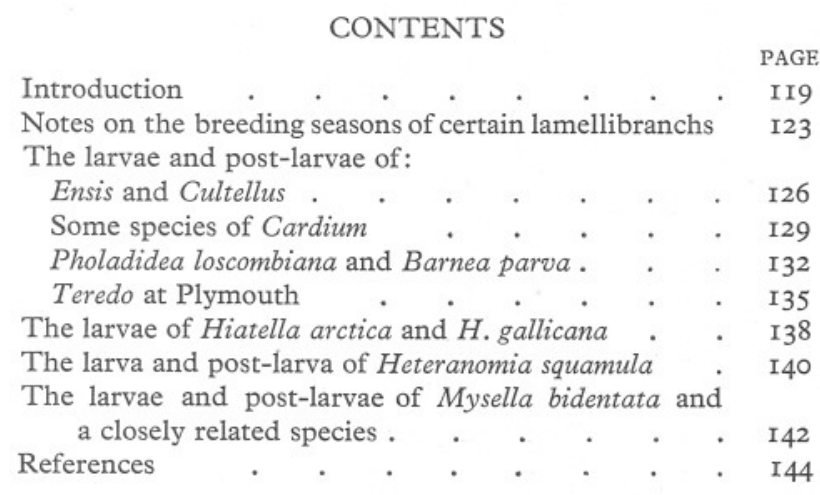

\section{INTRODUCTION}

A study of the larval stages of different lamellibranchs from Plymouth with a view to determining their importance in the plankton has brought out some interesting facts. It is well known that the free-swimming larvae are much simpler than most of the gastropod veligers, and that the velum is usually entire, having rarely a slight indentation, showing a tendency to be bilobed in the larger forms. They thus resemble in this respect the primitive gastropods. In many of them the velum is lost early in life, and usually the change in form of the shell takes place after metamorphosis. The post-larval growth is therefore an important part of the life history. The first shelled stage is so similar in all species that it is almost impossible to distinguish the different early veligers in the plankton, but in certain cases fertilizations have been made and the larvae reared until they have lost the velum and descend to the bottom when the species, or at least the genus, can usually be identified.

Fertilizations were found to be difficult. Those which were successful were made in finger-bowls in the usual way, in sterilized or filtered water, the freeswimming larvae being transferred to plunger jars or small bowls with minute flagellates for food. Veligers from the plankton were kept in bowls or plunger jars with flagellates or diatoms for food until they grew to a stage in which the 
species or genus was recognizable. In this way much useful knowledge has been gained. Adults of many species were examined to find the state of the gonads and the breeding seasons. This, together with the recognition of the larvae in the plankton, has shown many definite breeding periods, and certain veligers at times dominate the plankton, such as Mytilus edulis in late spring and early summer and Ensis siliqua in early spring.

Descriptions of the larvae and post-larvae of Lima hians and of Kellia suborbicularis have already been published (Lebour, 1937-1938). Notes on several other species are given below; though unfinished it is thought best to publish them now, since the work must be discontinued for a period owing to my absence from Plymouth.

Knowledge of the later lamellibranch larvae and post-larvae is slight except for those which are economically important. References to these latter are purposely omitted in the list of literature, and only a selection of the more important papers relating to lamellibranch larvae is here included. The bulk of the previous work has been done on the egg and newly hatched larva. We have, however, the researches of Drew (I90I) on Nucula and Yoldia, Odhner (19I4) on various larvae from Rovigno, Pelseneer (1926) on Lucina, and Kändler (1926), who reared several planktonic veligers to recognizable forms, his work being quoted extensively by Haas in Bronn's Tierreich (1929, 1937). Thorson (1935) described the eggs and young of Musculus, and Matthews (I9I3) reared Mytilus edulis from fertilization to the young sessile stages. All these papers deal with species which occur in Britain or with closely related forms. In Japan Miyazaki (1935, I936) has reared several species from fertilizations to young sessile stages.

The descriptions show that most of the essential external changes take place after the velum is lost. This, however, does not by any means indicate that the free-swimming larvae are of no account in the plankton, for they are often present in very large numbers and are known to be eaten by many planktonic and other animals. They are found in very small herring before the loss of the yolk sac, and young sprat of whitebait size frequently have their stomachs full of early veligers (Lebour, I92I). The best food for rearing crab larvae was found to be the larvae of the common oyster taken from the gills of the parent, and Teredo larvae one day old, obtained from fertilizations, were also found useful for this purpose (Lebour, 1927). Many small invertebrates eat lamellibranch larvae; to quote but one instance, the larvae of the annelid Magalona is always found to be feeding on them (Lebour, 1922).

Most lamellibranch veligers are small, the largest being well under $0.5 \mathrm{~mm}$. long. A striking fact shown in the present study is that some of the largest veligers belong to very small adults. Thus an unusually large larva is found in Kellia suborbicularis, reaching to $0.32 \mathrm{~mm}$. in shell length, the outstretched velum being still larger (Lebour, 1938), and two only slightly smaller turn out to be closely related forms, Mysella bidentata and a species which is possibly undescribed (see below, p. I43). Both Kellia and Mysella are small when adult, 
Kellia breeding at a shell length of from 4 to $9 \mathrm{~mm}$., while Mysella is still smaller. Both are viviparous; the larvae are retained in the gill pouch until an early shelled stage, and the remainder of the larval life is continued for some time freely in the sea. All of these veligers are round or roundish.

Lima is a striking member of the plankton in its larval stage (Lebour, 1937) at certain times of the year; it often occurs with Kellia, and is easily recognizable by its triangular wedge-shaped shell attaining a large size before losing the velum. Hiatella arctica also grows to a large size, the shell being triangular with its greatest diameter lengthways. Kellia, Lima and Hiatella arctica are the commonest large lamellibranch larvae at Plymouth. Of these Kellia may occur throughout the year, the others chiefly in late summer and autumn. Hiatella gallicana breeds in winter and its larva, smaller than that of $H$. arctica, occurs in winter and early spring. Heteranomia squamula is also easily recognizable in the plankton on account of its very conspicuous pedal sinus (see below, p. I40), Anomia being similar but without such a distinct sinus. Both occur irregularly throughout the year, Heteranomia especially in autumn and winter. Ensis siliqua characterizes the plankton in early spring, apparently its only breeding season; the larva can be recognized by its oval shell curving in dorsally behind and by its bright yellowish brown liver. The closely related larva of Cultellus pellucidus occurs in autumn and winter and is distinguishable from Ensis by the red colour near the siphons in the late larva (see below, p. I28). Mytilus edulis is by far the commonest larva in May and June, occurring also sparingly at other times; it is recognizable by its conspicuous eye and purplish tinge. Pecten larvae and their near relatives also have conspicuous eyes, but the shell is more oval and not tinged with purple; moreover, early post-larvae are often seen with the beginning of the shell sculpture peculiar to these forms. Closely related to Mytilus is the larva of Musculus. This is larger than Mytilus, coloured dark brown and purplish and with the shell rounder.

Cardium larvae are small and inconspicuous except those of Cardium crassum, which grow to a large size and are conspicuous members of the plankton in the summer months (see below, p. 132). Another easily recognizable veliger is Teredo, almost certainly T. norvegica, which is almost spherical and very globose, occurring at almost any time of year, sometimes in numbers. A second Teredo veliger, found inside the parent and swimming about round the wood in which it burrows, is probably closely related to $T$. navalis (see below, p. 136). Pholadidea and Barnea lose the velum at a very early stage and are difficult to recognize in the plankton (see below, p. 132). Venus fasciata has a small round veliger, and probably the other members of the genus have similarly shaped larvae difficult to distinguish. Among the numerous small roundish and oval veligers that of Abra sp. (probably Abra alba) can be recognized and a few others guessed at, but there are still very many not identified. Nucula nucleus and N. nitida have free-swimming larvae; the egg of $N$. nucleus has been reared from a fertilization to a barrel-shaped larva similar to that described by Drew for N. proxima. It has been shown by Drew 
(I90I) that there is no typical velum in the family, but that the velar cells enwrap the larva in a case. The free-swimming stage is apparently very short in these two British species, for perfectly formed shells similar to the adults occur at a very small size.

It is found that a large number of different species of lamellibranch veligers occur in late summer and autumn, apparently after the second large diatom outburst. Although there are always some larvae present in the plankton more species occur at this season. The winter months have the fewest species; in spring and summer they are plentiful, but the plankton is frequently characterized by one predominating species.

A few lamellibranchs retain the larvae in the gill pouch until they have the adult form. This occurs in Lasaea rubra. Certain species of Musculus, as is shown by Thorson (1935), deposit their eggs in gelatinous strings, the young emerging as miniature adults. Several species are viviparous, notably the Erycinidae and their near relatives.

A table is given showing the fertilizations which have been successful. All those which resulted in egg division are marked. Cardium edule, Cardium scabrum and Pholadidea loscombiana were reared until they lost the velum and descended to the bottom. Ensis siliqua, Barnea parva, Teredo norvegica, Hiatella gallicana, Spisula solida and Heteranomia squamula were reared to the shelled larva, Nucula nucleus to the free-swimming larval stage.

\section{Table I. Successful Fertilizations}

Nucula nucleus

Nucula turgida

Heteranomia squamula

Mytilus edulis

Chlamys opercularis

Cardium scabrum

Cardium edule

Venus ovata

Venus fasciata

Venus striatula

Paphia rhomboides

Paphia pullastra

Tellina crassa

Scrobicularia plana

Abra alba

Cultellus pellucidus

Ensis siliqua

Spisula solida

Aloidis gibba

Hiatella gallicana

Gastrochaena dubia

Barnea parva

Pholadidea loscombiana

Jan. Feb. Mar. Apr. May June July Aug. Sept. Oct. Nov. Dec.

Teredo norvegica

Thracia convexa

Any month

Viviparous species extruding larvae:

Kellia suborbicularis

Galeomma turtoni 
The study of the post-larval stages has shown that two species exist of certain forms. Thus it is conclusively proved that Hiatella gallicana and $H$. arctica are distinct species, a fact often denied, but recognized by Winckworth (1932) and others. One breeds in winter, the other in spring, and the shelled veligers, as already shown by Odhner (I9I4), are easily distinguished. From the study of the post-larvae it is found that besides Mysella bidentata there is another very closely related species. The post-larval growth, that is to say the growth after the loss of the velum, is most interesting in many species, especially in the Pholadidae and Teredinidae. In Pholadidea loscombiana certain phases occur which are intermediate between the veliger and adult and peculiar formations are found in Teredo. The post-larval phases in Pholadidea seem to indicate a habit of life intermediate between swimming and boring which apparently lasts for a long time. The very young Pholadidea are never seen in the rock, and it may be that there is a prolonged period of crawling before any boring takes place.

\section{Notes on the Breeding Seasons of Certain Lamellibranchs}

(The names are according to Winckworth, I932)

Nucula nucleus (L.). Fertilized successfully in July, September, October and November. Reared to barrel-shaped larvae in July. No eggs or ripe sperm seen from December to March. Breeding from spring to early autumn. Eggs $0.10 \mathrm{~mm}$.

Nucula hanleyi Winckworth. Breeding at the same time as Nucula nucleus.

Nucula turgida Leckenby \& Marshall. Fertilized successfully in February and reared to free-swimming early larvae. Breeding in winter. Eggs $0.09 \mathrm{~mm}$.

Glycimeris glycimeris (L.). Ripe eggs obtained in January, March and October; ripe sperm in January and March.

Arca lactea L. Ripe eggs in September and October; ripe sperm in January, June, September and October.

Anomia ephippium L. Ripe eggs in June and October. Larvae of this species or Monia are found in the plankton at any time of year.

Heteranomia squamula (L.). Successful fertilizations obtained in May and the larvae grew to an early shelled stage. Ripe eggs and sperm found at any time of year. Larvae are common in the plankton throughout the year but especially in autumn and winter when the breeding season is more intense.

Mytilus edulis L. Successful fertilizations obtained in May and the larvae grew to the young shelled stage. Mrs Matthews (I913) grew them successfully to young mussels. The chief breeding season is from April to June, but some may be found ripe at almost any time.

Modiolus modiolus (L.). Ripe eggs and sperm in December.

Musculus sp. (probably M. marmoratus (Forbes)). Veligers common in the plankton in late summer and autumn. Thorson (1935) found the eggs of $M$. discors and $M$. niger from East Greenland in strings close to the parent in Ascidians; they hatched out after the loss of velum. He states that $M$. marmoratus has small eggs hatching as veligers and it is therefore probable that the present species is M. marmoratus.

Chlamys varia (L.). Ripe eggs in July.

Chlamys distorta (da Costa). Ripe eggs and sperm in March and July.

Chlamys opercularis (L.). Eggs and sperm were given out in the laboratory tanks on May 25 I936. The eggs were successfully fertilized and grew to the young shelled stage. Post-larval stages are found throughout the year. 
Chlamys tigerina (Müller). Ripe eggs and sperm in January. Larvae of Chlamys spp. not identified occur in any month of the year.

Lima hians $(\mathrm{Gm}$.). Breeding from late summer to early spring. Larvae are most frequent in late summer and early autumn and are common in the plankton.

Astarte sulcata (da Costa). Ripe eggs were obtained in July and October, and ripe sperm in January and July.

Phacoides borealis (L.). Ripe eggs and sperm in March and April. Pelseneer (I926 as Lucina lactea) describes stalked egg capsules deposited on the sand.

Kellia suborbicularis (Montagu). Viviparous, giving out small shelled larvae from the gill pouch. Embryos found developing in the gill pouch in May, July and August; ripe sperm in May and October. The species apparently breeds throughout the year, as the larvae are present in the plankton in any month; but they are specially common in late summer and early autumn. Post-larvae have been found crawling on red rock and in rock crevices.

Galeomma turtoni Sowerby. Viviparous. Free-swimming embryos at an early stage without a shell were given out in September (obtained by Miss M. L. Popham).

Mysella bidentata (Montagu). Viviparous. Late veligers are common in the plankton in summer and autumn. Post-larvae and young are found in shell sand in autumn.

Mysella sp. Veligers common in the plankton in summer and autumn.

Cardium echinatum L. Nearly ripe eggs and ripe sperm found in January, April, May and September. Larvae have been taken in the plankton at various times.

Cardium scabrum Philippi. Fertilized eggs were obtained in July and were reared until the loss of the velum.

Cardium edule L. Breeding from spring to early autumn, chiefly May to August. Successful fertilizations were obtained from April to October and the larvae reared until the loss of the velum.

Cardium crassum $\mathrm{Gm}$. Hermaphrodite. Apparently ripe eggs and ripe sperm found in almost any month. Larvae are taken in the plankton through spring and summer, and are often very plentiful.

Dosinia exoleta (L.). Apparently ripe eggs and ripe sperm in February and July.

Venus verrucosa L. Ripe eggs and sperm in April.

Venus ovata (Penn.). Breeding from March to October. Successful fertilizations were obtained in September and October and the larvae reared to an early freeswimming stage.

Venus casina L. Breeding throughout the year.

Venus fasciata (da Costa). Breeding throughout the year. Successful fertilizations were obtained in July and November, and the larvae reared to an early freeswimming stage.

Venus striatula (da Costa). Breeding in February, March and May. Eggs were successfully fertilized in February and May and reared to an early free-swimming stage.

Paphia rhomboides (Penn.). Breeding in October, November, December, February and March.

Paphia pullastra (Montagu). The chief breeding season is in summer, but the species breeds also in autumn. Successful fertilizations were obtained in June and September, and the larvae reared to an early shelled stage.

Paphia decussata (Gm.). Ripe eggs and sperm were found in summer months and also in December.

Tellina tenuis da Costa. Ripe eggs and sperm in May.

Tellina crassa Penn. Usually breeding in summer, but ripe eggs and sperm were also found in January. Successful fertilizations were obtained in July and the larvae reared to an early free-swimming stage.

Macoma balthica (L.). Active sperm in July. 
Scrobicularia plana (da Costa). Breeding in summer. Eggs were successfully fertilized in June and July, and the larvae reared to an early free-swimming stage.

Abra alba (S. Wood). Breeding in summer. Successful fertilizations were made in May, August and October, and the larvae reared to an early free-swimming stage.

Gari tellinella (Lam.). Breeding in summer.

Solecurtus chamasolen (da Costa). Breeding in summer.

Solecurtus scopula (Turton). Nearly ripe eggs and sperm in July.

Cultellus pellucidus (Penn.). Breeding in late summer and winter, especially in winter. Successful fertilizations were made in September, but the eggs were reared only to the gastrula. Larvae are found in the plankton in autumn and winter.

Ensis siliqua (L.). Breeding in early spring. Eggs successfully fertilized in March and April were reared to an early shelled stage. Larvae are taken in the plankton in early spring.

Spisula solida (L.). Breeding in winter and early spring. Successful fertilizations were obtained in January and February, and the larvae reared to an early shelled stage.

Spisula subtruncata (da Costa). Active sperm in November and January; nearly ripe eggs in November.

Mya truncata L. One hermaphrodite with nearly ripe eggs and active sperm in May.

Aloidis gibba (Olivi). Successful fertilizations in April were reared to the gastrula stage.

Hiatella gallicana (Lam.). Breeding chiefly in winter, but also in spring. Eggs successfully fertilized in January, February, April, May and December were reared to an early shelled stage. Larvae are taken in the plankton chiefly in winter. Post-larvae are found in winter, crawling on red rock, into which they bore.

Hiatella arctica (L.). Breeding in summer. Larvae are taken in the plankton throughout the summer and autumn. They are especially common in late summer and early autumn.

Gastrochaena dubia (Penn.). Successful fertilizations were made in January and the larvae reared to the gastrula.

Barnea parva (Penn.). Breeding in summer and early autumn. Successful fertilizations were made in October and the larvae reared to an early shelled stage. The postlarva was reared in a plunger-jar from planktonic veligers taken in May.

Pholadidea loscombiana Turton. Breeding in autumn. In December nearly all were found to be spent females or males, and later all males. Eggs fertilized in September, October and November were reared until the loss of the velum and the beginning of post-larval growth.

Teredo norvegica Spengler. Breeding throughout the year. Successful fertilizations can be made at any time and the eggs were reared to the early shelled larvae. Veligers, almost certainly belonging to this species, are taken in the plankton in any month, especially in autumn.

Teredo sp. Viviparous. Adults with late veliger larvae were found in spring, but probably occur at other times also.

Thracia phaseolina (Lam.). Four hermaphrodite specimens nearly ripe were taken in July.

Thracia convexa (W. Wood). One hermaphrodite. The eggs were fertilized successfully in September and reared to the gastrula. 


\section{The Larvae and Post-larvae of ENSIS and CUltellus}

We know little of the breeding and larval stages of the Solenidae. Kändler (I926) at Heligoland reared Cultellus pellucidus from a planktonic veliger, with the shell $0.37 \mathrm{~mm}$. long or less, to a young stage I mm. in length. The larval shell has a characteristic shape, narrowing at the anterior end, with a very conspicuous golden brown liver. The same shape, but with the anterior end slightly blunter, and a similarly coloured liver distinguish the larva of Ensis siliqua at Plymouth, which I have reared in a similar way until the characteristic teeth of Ensis were seen. This larva is very like that of Cultellus but differs in certain constant features noted below.

\section{Ensis siliqua (L.) (Figs. I $a-g$ )}

This species is very common in sandy shores in the neighbourhood of Plymouth, especially at Millbay, Salcombe, and at Whitsand Bay. It was breeding freely in March and April, and in the early spring months the larvae characterized the plankton. Since these larvae rapidly disappeared towards early summer and the Ensis examined at other times of year were never ripe, it may be assumed that early spring is the usual breeding season here. Successful fertilizations were effected in March and April, the larvae growing to the shelled stage (Fig. I $a$ ) and then dying. Later larvae in the plankton were reared until the genus could be recognized.

Ensis siliqua is the only really common species (it is confused with Ensis ensis in the Plymouth Fauna List, I93I) and since the presence of the larvae in the plankton naturally followed the breeding of the species it may be safely assumed that the larvae are those of E. siliqua. Numbers taken at Millbay and Salcombe in March and April were ripe, and at other seasons no specimen examined was found to be breeding. Both ovaries and testes are cream-coloured and in the breeding season are very full of eggs and sperm. The eggs are small, $0.07 \mathrm{~mm}$. in diameter, with a very thin membrane and no gelatinous covering. Shelled larvae were obtained in bowls from the fertilizations in two days. The shells were $0.10 \mathrm{~mm}$. in length and slightly less in depth, the hinge being almost straight but slightly hollowed in the centre (Fig. I $a$ ). The velum was about half the length of the shell, and was surrounded by long cilia, but no large central cilium could be seen. These larvae did not live. Larvae of all sizes, from 0.16 to $0.35 \mathrm{~mm}$. in length, abound in the spring plankton (Fig. I $b-d$ ), and some are seen even as early as February, dwindling at the end of April and almost absent in May and later. They resemble very closely the larvae of Cultellus pellucidus described by Kändler (1926), but the late larval stages and post-larvae do not have the characteristic orange-red pigment round the posterior mantle edge found in that species. Both have a very conspicuous golden brown liver, the shell being irregularly oval, narrowing 


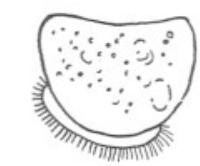

$a$
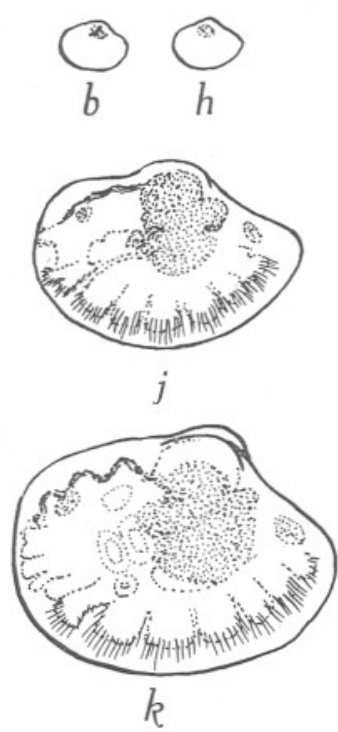
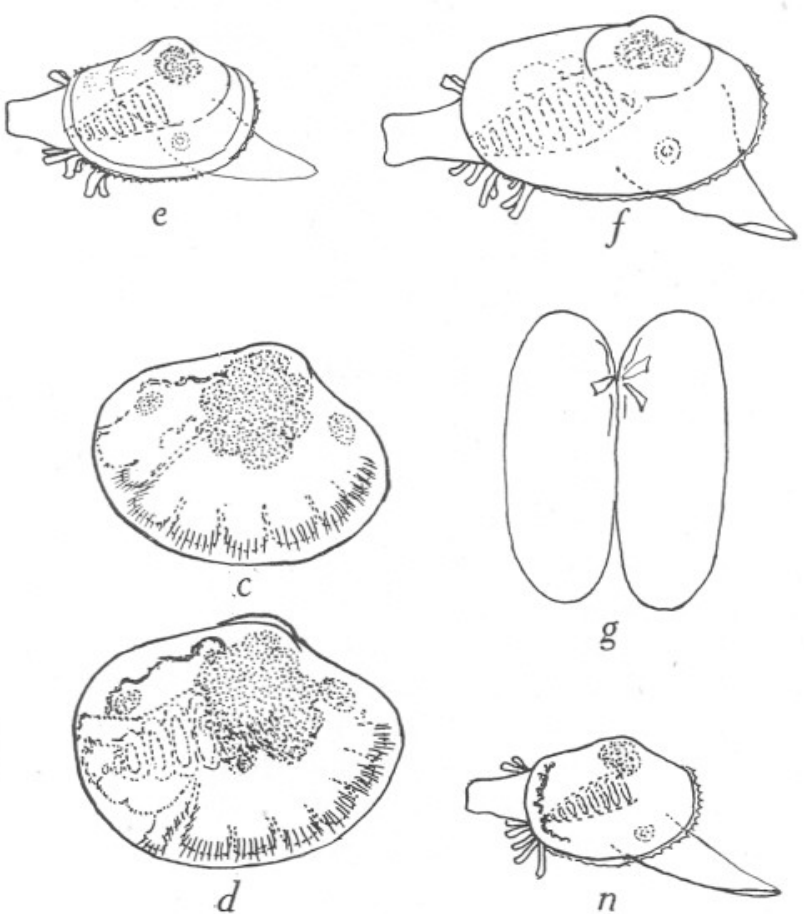

$n$

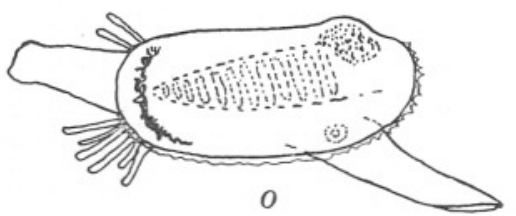

Fig. I.

$a-g$, Ensis siliqua.

$a$, shelled larva from fertilization, $0.10 \mathrm{~mm}$. long; $b$, smallest larva found in plankton, $0.16 \mathrm{~mm}$. long; $c$, later larva from plankton, $0.28 \mathrm{~mm}$. long; $d$, later larva just before losing velum, $0.35 \mathrm{~mm}$. long; $e$, post-larva, grown in plunger-jar from planktonic veliger, $0.48 \mathrm{~mm}$. long; $f$, post-larva, grown in plunger-jar from planktonic veliger, $0.72 \mathrm{~mm}$. long; $g$, shell of post-larva, grown in plunger-jar from planktonic veliger, showing teeth, $0.72 \mathrm{~mm}$. long.

$$
h-o, \text { Cultellus pellucidus. }
$$

$h$, smallest larva seen in plankton, $0.16 \mathrm{~mm}$. long; $j$, later larva from plankton, $0.24 \mathrm{~mm}$. long; $k$, later larva from plankton, nearly ready to metamorphose, $0.32 \mathrm{~mm}$. long; $l$, later larva from plankton just before losing velum, $0.36 \mathrm{~mm}$. long; $m$, post-larva grown in plungerjar from planktonic veliger, $0.38 \mathrm{~mm}$. long; $n$, post-larva grown in plunger-jar from planktonic veliger, $0.4 \mathrm{~mm}$. long; $o$, post-larva grown in plunger-jar, $0.72 \mathrm{~mm}$. long. 
anteriorly, and rounded posteriorly, the umbo being prominent. The anterior end is sharper in Cultellus than in Ensis. In the larva of Ensis siliqua at $0.28 \mathrm{~mm}$. long (Fig. I c) the velum is well developed and the animal is in much the same stage as Kändler's Cultellus pellucidus at $0.30 \mathrm{~mm}$. At $0.35 \mathrm{~mm}$. (Fig. I $d$ ), the largest larva seen, it is nearly ready to metamorphose but still retains a large velum. Five to seven gill slits may be present-a higher number than in Kändler's Cultellus at $0.36 \mathrm{~mm}$. which has lost the velum-but the tentacles in the siphonal region have not yet appeared. There is, however, irregularity in the growth of the organs and in the size of the larva in both species at Plymouth.

These late larvae metamorphosed in a plunger-jar and became much elongated posteriorly, the original embryonic shell being still fairly conspicuous (Figs. I $e-g$ ). At $0.48 \mathrm{~mm}$. the velum has completely disappeared, there are several gill slits and the siphons have developed with ciliated tentacles at their base, two above the dorsal siphon, which has a long extensile valve, and four below it, and two below the ventral siphon, as in Cultellus (Fig. I $e$ ). Later post-larvae were $0.72 \mathrm{~mm}$. in length (Fig. I $f, g$ ) and showed the typical teeth of Ensis (Fig. I $g$ ), one cardinal in the right valve and two in the left, besides laterals. The foot is very large and powerful with a blunt flat tip and is capable of extensive jerky movements. Such older stages were in the plunger jars in January, having grown from the early spring veligers. It is probable, however, that they grew slowly and that in nature they would have attained this length much sooner.

\section{Cultellus pellucidus (Pennant) (Figs. I $h-o$ )}

This species is often dredged in silty sand both inside and outside the breakwater, especially inside. It breeds in autumn and winter. Kändler found it breeding in Heligoland in November. Only one ripe female has so far been found at Plymouth at the same time as a male, and a partially successful fertilization was obtained at the end of September. All specimens examined in spring and summer were unripe except one male full of active sperm in July. The eggs from the fertilization only developed as far as a few segments.

Larvae attributable to this species and closely resembling those described by Kändler occur fairly commonly in the plankton in autumn and winter (November to January). The smallest seen was $0.16 \mathrm{~mm}$. in length (Fig. I $h$ ), the largest $0.36 \mathrm{~mm}$. (Fig. I $l$ ). They resemble very closely the larvae of Ensis, but the shell is more pointed anteriorly and the post-larvae are decidedly narrower in the shell. The orange-red pigment in the late larvae and postlarvae at the posterior end inside the mantle distinguishes them at once, as Kändler has already shown. Specimens grown in plunger-jars from the winter larvae in July measured 0.38 to $0.72 \mathrm{~mm}$. (Figs. I $\mathrm{m}-0$ ), the smallest being fully metamorphosed and agreeing well with Kändler's description. 


\section{The LaRvae and Post-Larvae of Some Species of CardiUM}

It has been possible to differentiate between several Cardium larvae at Plymouth and to follow the growth of Cardium edule and Cardium scabrum from the egg to metamorphosis and post-larva.

The larva of Cardium crassum (Laevicardium) is easily recognized in the plankton and also another species which is almost certainly C. echinatum. Cardium edule and C. scabrum were reared from the fertilized egg to the time of metamorphosis and loss of velum. Cardium crassum, which is hermaphrodite, was not fertilized as up to the present it has not been possible to obtain really ripe eggs; but the larva, which is at times common in the plankton, was reared to a stage in which the species was recognizable. The veliger is much larger than that of either Cardium edule or C. scabrum, and the shell is smooth in the post-larva, even in those up to more than $\mathrm{I} \mathrm{mm}$. in length. Cardium echinatum was never obtained in a sufficiently ripe condition for successful fertilization, but the larva almost certainly attributable to this species is very unlike the others.

\section{Cardium edule L. (Figs. $2 a-j$ )}

Little is known of the late larval and post-larval stages of this species; it loses its velum very early and the ribs only appear after metamorphosis. At Plymouth it breeds in the late spring and summer months, although occasional exceptions may be found at other times. The veligers are chiefly found up the estuaries or in the sea near their openings in spring and summer. Successful fertilizations were made in April, May, June, July, August and September. The larvae were reared in bowls until the velum was lost, but they did not live to put on any ribs. Early and late veligers from the plankton corresponded with those reared, and post-larvae showing the same-sized embryonic shells were found in tow-nettings taken near the bottom in the estuaries. Later young stages were found in the estuaries. At Neal Point, in the Tamar Estuary, early in July, they were about I $\mathrm{mm}$. in length, showing that spawning must have taken place some time before.

The eggs (Figs. $2 a, b)$ are covered with a thin membrane and a large gelatinous envelope in which development takes place until the veliger emerges. The unfertilized egg is $0.05 \mathrm{~mm}$. across and is opaque with a large nucleus. It is surrounded by the closely fitting membrane which soon disappears, the large gelatinous covering being $0.16-0.18 \mathrm{~mm}$. in diameter. The free-swimming veliger 3 days after fertilization measured $0.14 \mathrm{~mm}$. in length; the hinge line of the shell was straight, the valves roundish and flat. The velum, armed with powerful cilia round the margin and a large central flagellum, was about half the length of the shell (Figs. $2 c, d$ ). The internal organs were forming. In three weeks the shell was $0.16 \mathrm{~mm}$. long (Fig. $2 e$ ), 
the growth probably being slower than in natural conditions, and in five weeks it had increased to $0.30 \mathrm{~mm}$. in length, the shell being nearly round and still perfectly smooth (Fig. $2 f$ ). It now lost the velum and descended to the bottom. Although living for some time after this the reared larvae ceased to grow and eventually died.

Veligers of all sizes in the inshore plankton were similar to the reared specimen and none were larger than the largest reared. These, grown in plunger-jars and bowls, put on ribbed growth, the ribs at first being always very irregular. A growth of $0.05 \mathrm{~mm}$. in three days was noticed in one. In all these post-larvae the embryonic shell can be recognized. Specimens I mm. in length from mud from the estuary show ribs more like the adult, but unarmed, and long tentacles in connexion with the siphons. The embryonic shell is still conspicuous (Figs. $2 g-j$ ). Although so small the enormous numbers of these veligers must be very important in the plankton of the estuaries and inshore waters.

\section{Cardium scabrum Philippi (Figs. $2 k-q$ )}

This species is common in certain parts of the Sound and outside, especially on or in the crevice of the red rock dredged from Stoke Point grounds. Besides adults many post-larvae were found in this locality on the rock, often in small holes. Two adults were put together in a bowl and the next morning many eggs had been extruded. As these were all fertilized and beginning to segment, both a male and a female were probably present. The eggs lived and developed into larvae, some of which did well in bowls and reached the stage in which the velum was lost and the animal descended to the bottom. As with Cardium edule they grew no further, never putting on any ribs, and eventually they died.

Young Cardium scabrum are easily identified and many were reared from the planktonic veligers to a late post-larval stage in plunger-jars. The egg is similar to that of $C$. edule and almost the same size, the larva remaining in the gelatinous covering until it emerges as a free-swimming veliger (Fig. $2 k$ ). The free-swimming shelled stage is at first very like that of $C$. edule but soon puts on concentric striations which are characteristic (Figs. $2 l, m$ ). At 3 days old the shell is $0.08 \mathrm{~mm}$. long, growing only to the small size of about $0.16 \mathrm{~mm}$. long before losing the velum. The late larval shell is rather more oblong than in C. edule, and the concentric striae and small size at metamorphosis distinguish it. Post-larvae grown in plunger-jars from planktonic veligers put on irregular ribs, with the embryonic shell exactly similar to those reared from the egg showing very clearly (Figs. $2 n, p$ ). The post-larvae are very much elongated posteriorly and nearly straight on the posterior dorsal margin which is highly spinous as are also the posterior ribs. Specimens about $\mathrm{I} \mathrm{mm}$. long are clearly distinguished from those of Cardium edule of the same size. At about $8 \mathrm{~mm}$. the young shell is very like the adult and has become much rounder. 

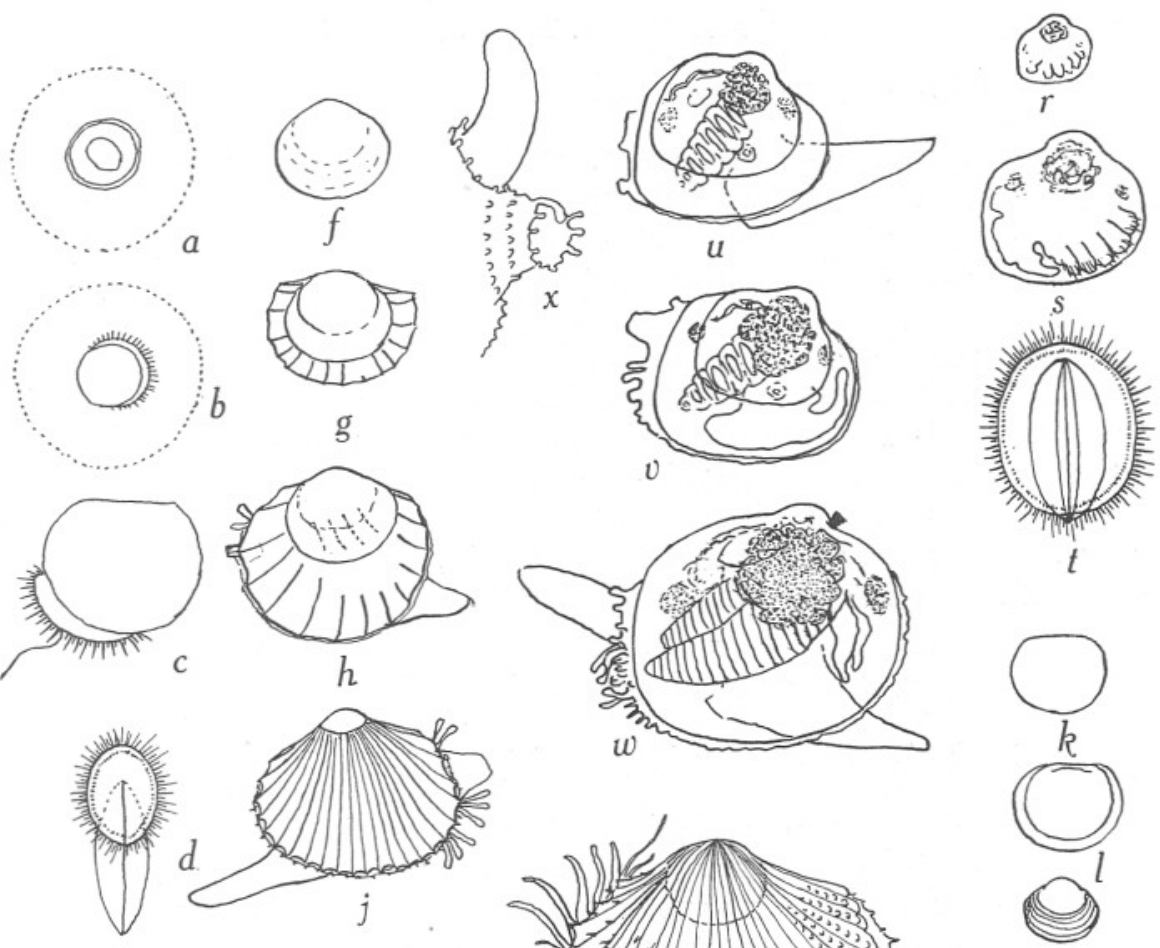

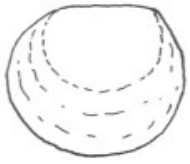

e

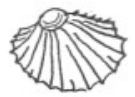

$n$
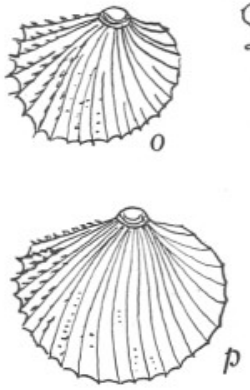
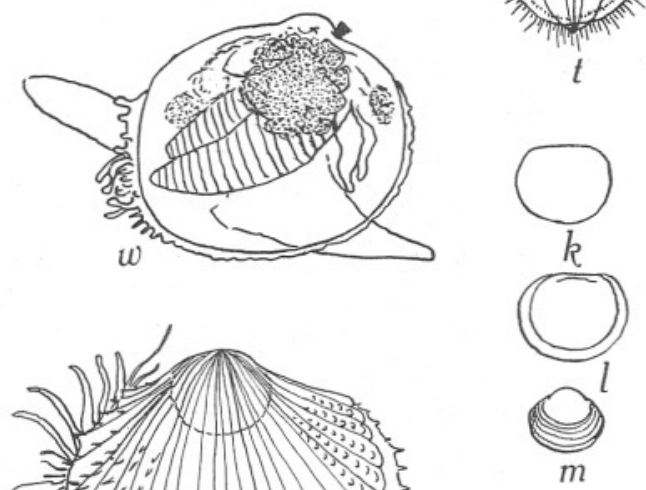

Fig. 2.

$a-j$, Cardium edule.

$a$, unfertilized egg, gelatinous covering, $0.18 \mathrm{~mm}$. across; $b$, embryo in gelatinous covering, 24 hours old, from fertilization; $c$, free-swimming larva, 3 days old, reared from egg, shell $0.14 \mathrm{~mm}$. long; $d$, the same swimming; $e$, older larva $0.16 \mathrm{~mm}$., reared from egg; $f$, postlarva reared from egg, aged 5 weeks, $0.30 \mathrm{~mm}$. long, having lost the velum; $g$, post-larva grown in bowl from planktonic veliger, $0.4 \mathrm{~mm}$. long; $h$, later post-larva grown in plungerjar from planktonic veliger, $0.48 \mathrm{~mm}$. long; $j$, young Cardium edule, $\mathrm{I} \mathrm{mm}$. long from mud, Neal Point.

\section{$k-q$, Cardium scabrum.}

$k, l$, very young shells from fertilization, $0.07-0.08 \mathrm{~mm}$. long; $m$, the same at loss of velum, $0.16 \mathrm{~mm}$. long; $n$, post-larva grown in bowl from planktonic veliger, $0.56 \mathrm{~mm}$. long; $o$, $p$, later post-larvae grown in plunger-jar from planktonic veliger, $0 \cdot 8-\mathrm{I} \cdot \mathrm{I} 2 \mathrm{~mm}$. long; $q$, Cardium scabrum, $8 \mathrm{~mm}$. long.

$$
r-x, \text { Cardium crassum. }
$$

$r$, smallest larva recognized from plankton, $0.2 \mathrm{~mm}$. long; $s, t$, late veliger from plankton, ready to metamorphose, $0.44 \mathrm{~mm}$. long; $u, v, w$, post-larvae reared from planktonic veligers in plunger-jars, $0.97-1.5 \mathrm{~mm}$. long; $x$, siphons of a slightly older specimen.

$y$, post-larva of Cardium echinatum (?) reared from planktonic veliger in plunger-jar, $0.83 \mathrm{~mm}$. long. 
Cardium crassum Gmelin (Figs. $2 r-x$ )

Veligers of this species are common at times in the plankton in spring and summer, both inside and outside the breakwater. They are quite unlike those of Cardium edule and C. scabrum; they grow to a much greater size before losing the velum, and the shell is almost square posteriorly and in the post-larvae quite smooth in specimens up to at least a length of $2.5 \mathrm{~mm}$. The smallest veliger recognized was $0.2 \mathrm{~mm}$. in length (Fig. $2 r$ ), and at metamorphosis and loss of velum it is about $0.4-0.45 \mathrm{~mm}$. The velum is large and in the late stages overlaps the valves to a considerable extent (Figs. $2 s, t$ ). Late larvae from the plankton reared in plunger-jars have the same square posterior end, the siphons gradually appearing with their tentacles, a very large and active foot, gill slits and conspicuous liver (Figs. $2 u, v, w$ ). A specimen was reared in a plungerjar to a shell length of $2.5 \mathrm{~mm}$., showing the characters of this species.

\section{Larva almost certainly attributable to Cardium echinatum L. (Fig. 2 y)}

A veliger occurs at times in the plankton in spring, summer and autumn which almost certainly belongs to Cardium echinatum. The only other species it could be is C. aculeatum, and this is not nearly so common in the neighbourhood. Unlike the three larvae described above its valves are very much inflated, the shell with its two valves being almost globular. The veliger reaches a length of $0.48 \mathrm{~mm}$. before metamorphosis. Specimens from the plankton reared in a plunger-jar put on growth with ribs and very sharp spines (Fig. $2 y$ ).

\section{Key to the LARVAe of THE ABOVE SPECIES OF CARDIUM}

A. Larvae very small at metamorphosis, valves flat:

(a) valves smooth (0.14-0.30 mm.) C. edule;

(b) valves with concentric striations $(0.07-0.16 \mathrm{~mm}$.) C. scabrum.

B. Larvae large at metamorphosis:

(a) valves fairly flat, square posteriorly (latest larva $0.44 \mathrm{~mm}$.) C. crassum;

(b) valves much inflated, round (latest larva $0.48 \mathrm{~mm}$.) C. echinatum (?).

\section{The Larvae and Post-larvae of Pholadidea loscombiana AND BARNEA PARVA}

All the free-swimming larvae known which belong to the Pholadidae have a more or less round shell and lose the velum at a small size. Kändler (I926) reared a species of Pholas (the species not identified but he thinks it is probably Pholas dactylus or $P$. crispata) from the planktonic veliger to a post-larva beginning to elongate. Miyazaki (I935) reared the Japanese species Parapholas quadrizonata up to a fairly late veliger from an artificial fertilization. In all these the embryonic shell (that is to say up to the period of metamorphosis) is round or nearly round, the elongation coming on later. 
At Plymouth successful fertilizations were made of Pholadidea loscombiana and of Barnea parva. Unknown veligers from the plankton reared in plungerjars developed into post-larvae almost certainly attributable to these two species, and in all of these the embryonic shell was small and nearly round. The veligers are so small and inconspicuous even in the late stages that it is very difficult to recognize them in the plankton, but when post-larval growth begins there are characteristics by which members of the family can be recognized. Pholadidea loscombiana was reared from the egg to the metamorphosis when it lost the velum, and to a post-larval stage in which it put on some anterior growth, but the post-larvae did not live longer. Post-larvae in the plungerjars reared from veligers taken from the plankton almost certainly belong to this species, as well as a post-larva found on the surface of the red rock from Stoke Point grounds. As none of these grew to a sufficiently late stage the identification is, however, not certain. The fertilization of Barnea parva grew only as far as the early shelled stage. A post-larva found in a plunger-jar almost certainly belongs to this species and shows that it assumes the adult form at an extremely small size. Shell growth in the post-larvae of Kändler's Pholas and of both the forms mentioned above is put on anteriorly and posteriorly, the anterior growth beginning first in Pholadidea.

\section{Pholadidea loscombiana Turton (Figs. $3 a-0$ )}

This species is common round Plymouth, boring in rocks, especially in the red rock dredged at Stoke Point grounds. It breeds in autumn and winter, and in spring and summer is always unripe, or there are only males. Eggs were fertilized successfully in February, the end of September, October and November. Active sperm and apparently ripe eggs were seen in January and March, but fertilizations were not successful. Sperm only was seen from May to July. November is the month when all appear to be ripe and when the most successful fertilizations were made. The proportion of the sexes at this time is about equal. Fertilizations were made in bowls of filtered water, the active larvae a day old being transferred to a plunger-jar containing outside seawater. Minute flagellates were given as food.

The unfertilized egg is pear-shaped and is $0.08 \mathrm{~mm}$. in length (Fig. $3 a$ ). When ripe the eggs are loose in the ovary. Both male and female gonads are cream-coloured and very large when ripe. When fertilized the egg contracted and became round, and was surrounded by a membrane (Fig. $3 b$ ). With the membrane it measured $0.05 \mathrm{~mm}$. It quickly lost the membrane and developed by the next day into a round larva, ciliated all over, with long hairs at one end. In two days there was a shell, $0.07 \mathrm{~mm}$. long, with a straight hinge (Fig. $3 \mathrm{c}$ ). The velum was about half as long as the shell and circular in outline, but no central flagellum was seen. The shell became rounder and the velum larger (Figs. $3 d, e$ ). Growth in the plunger-jar was very slow, the shell at four weeks old was only $0.24 \mathrm{~mm}$. long, although the organs were well developed and 
three gill slits present. At this size the shell was pointed at the anterior end and rounded posteriorly. The foot was large and active, the velum nearly as long as the shell, and the larva ready to metamorphose. The larva then lost

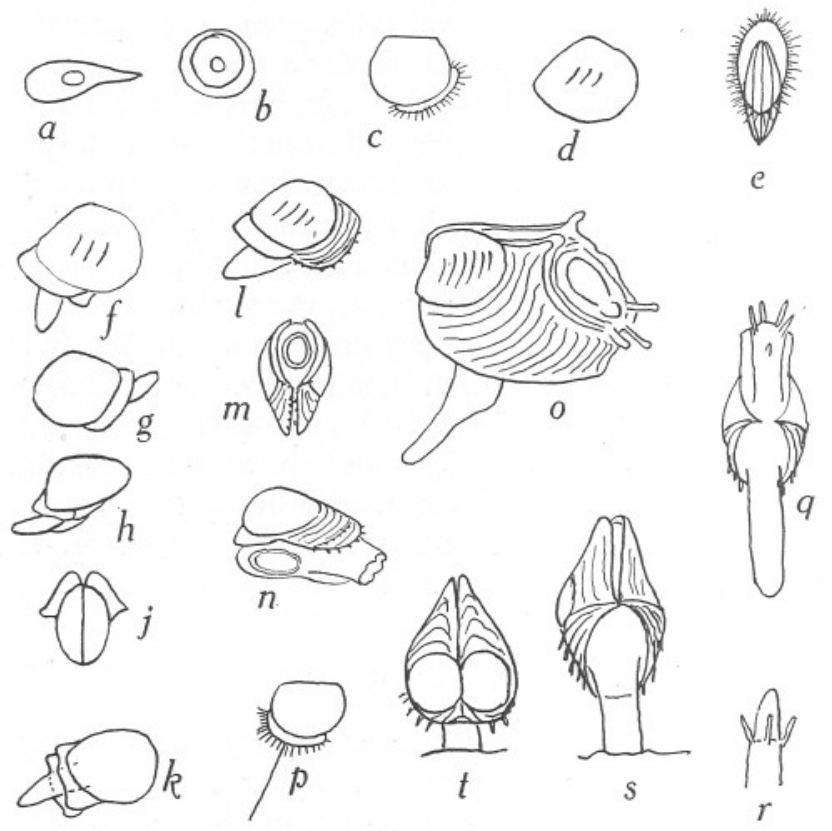

Fig. 3 .

$a-k$, Pholadidea loscombiana.

$a$, unfertilized egg, $0.08 \mathrm{~mm}$. long; $b$, fertilized egg, $0.05 \mathrm{~mm}$. long; $c$, early shelled veliger, $0.07 \mathrm{~mm}$. long, reared from egg; $d$, latest larva, $0.24 \mathrm{~mm}$. long, reared from egg; $e$, the same swimming; $f-k$, post-larvae $0.24-0 \cdot 26 \mathrm{~mm}$. long, reared from egg.

\section{$l-o$, probably Pholadidea loscombiana.}

$l, m, n$, post-larvae from surface of red rock, $0.27-0.32 \mathrm{~mm}$. long; $o$, post-larva reared from veliger in plunger-jar, $0.56 \mathrm{~mm}$. long.

$$
p-t \text {, Barnea parva. }
$$

$p$, shelled larva $0.06 \mathrm{~mm}$. long, reared from egg; $q, s, t$, young shell, $0.32 \mathrm{~mm}$. long, reared from planktonic veliger in plunger-jar; $r$, extended siphon.

the velum and descended to the bottom, putting on anterior shell growth (Figs. $3 f-k$ ). This growth was in the form of a smooth border on each valve turning outwards. No further growth took place and the larvae all died.

Post-larvae grown from unknown veligers in plunger-jars corresponded exactly with those reared from the egg, and having similar embryonic shells probably belong to this species (Fig. 30 ). The larvae reared from the egg were almost colourless until they lost the velum and then were yellowish with a purplish edge. The post-larvae from the plunger-jars were dark brown and purple and were possibly abnormal. A post-larval stage found on the 
surface of the red rock from Stoke Point grounds showed an anterior end very similar to that of the post-larva reared from fertilizations; it probably belongs to this species although it could not be kept alive long enough to be certain. It was $0.27 \mathrm{~mm}$. in length. The embryonic shell was similar to that of Pholadidea; it had the form of one of the Pholadidae, small spines at the edge of the posterior elongated part, and a large siphon.

It is curious that no very young Pholadidea were found in the red rock, although careful search was made for them. It is possible that the post-larvae crawl about for a long time before settling down.

\section{Barnea parva (Penn.) (Figs. $3 p-t$ )}

Breeding of this species appears to be in summer and early autumn. It is common in the rocks at Rum Bay and, more rarely, with Pholadidea in the red rock of the Stoke Point grounds. A successful fertilization was obtained on September I5 1937, in a bowl of filtered water. The eggs are similar to Pholadidea but slightly smaller. The larvae lived only to the first shelled stages, $0.05-0.06 \mathrm{~mm}$. across, and resembled Pholadidea but with a long central flagellum on the velum (Fig. $3 p$ ). The later veligers were not recognized in the plankton, but a young stage grown from a mixture of planktonic veligers in a plunger-jar is almost certainly this species; it has the form of Barnea and young Pholadidea, but the embryonic shell is considerably smaller than it is in Pholadidea, being only $0.08 \mathrm{~mm}$. in length and quite round. From the embryonic shell grow out two distinct portions, an anterior portion armed with spines and enclosing the foot, gaping very widely, and a posterior portion, the two parts of which can meet and enclose the siphon, but are also capable of gaping widely when the siphon is extended (Figs. $3 q, r, s, t$ ). This specimen is only $0.32 \mathrm{~mm}$. in its entire length, assuming the adult form very much earlier than does Pholadidea. The siphon is provided with tentacles surrounding a valve which is evertible.

\section{The Larvae and Post-larvae of Teredo at Plymouth}

Two species of Teredo occur boring in the raft near the breakwater, a small one closely related to Teredo navalis, but differing from it in certain important points, and Teredo norvegica. The first, like Teredo navalis, is viviparous. It keeps the veligers inside its body until they have attained a large size, the free veligers settling down on the wood and metamorphosing almost immediately they have left the parent. The second extrudes its eggs into the water before development takes place. Fertilizations were frequently made of Teredo norvegica, the larvae living until the young shelled stage. Late veligers, probably belonging to this species, occur fairly frequently in the plankton. In one instance one of these metamorphosed in a plunger-jar, and 
although not attached to wood grew to a post-larval stage in which the genus could be recognized. The larvae of the two forms are quite distinct and there is a great difference in the post-larvae.

\section{Teredo norvegica Spengler (Figs. $4 a-l$ )}

This species breeds throughout the year, judging from its eggs and sperm, which are ripe at any time. Fertilizations were frequently made during spring and summer when the larvae were used for feeding crab zoeae. The eggs are about $0.04 \mathrm{~mm}$. across. The early shelled larva is about $0.05 \mathrm{~mm}$. long with a straight hinge line and the velum is rather more than half the length of the shell (Figs. $4 a, b$ ). Later larvae, probably this species, from the plankton, are nearly spherical with a velum nearly as large as the shell and a long foot with which they sometimes swim; the shell is $0.32 \mathrm{~mm}$. long (Fig. $4 \mathrm{c}$ ). The latest larva is about $0.38 \mathrm{~mm}$. long with a very large velum reaching far beyond the shell (Figs. $4 d, e, f$ ). The sample of veligers from which the larvae metamorphosed possessed no eyes and came from inshore plankton in January. All through the autumn and winter they had occurred more frequently than at other times, although a few specimens may be seen in any month. The shell at metamorphosis is spherical and the one specimen which changed to a post-larva (Figs. $4 j, k, i$ ) became slightly larger before the growth anteriorly of four hook-like spines on each valve, and in the centre of the ventral margin a long pointed outgrowth ending in a long spine which prevents the valves from shutting. The foot is very large and powerful and the siphons projecting at the posterior end are armed with stout tentacles. Five pairs of gill slits are present. This specimen, reared from a late veliger in a plunger-jar, was unfortunately lost.

In the plankton there are found at times veligers very like those described above but possessing eyes, some in the shape of a crescent and some large and round (Figs. $4 g, h$ ). These also had the large foot which helped in swimming and were so similar in other ways that it seems probable that they belong to the same species and that some develop eyes and some do not.

\section{Teredo sp. (Figs. $4 m-p$ )}

This species differs from the description of Teredo navalis in its small size, the adults with young measuring under an inch in length, and in the shape of the pallets. It is hoped to investigate this further. Veligers of all sizes may be seen inside the body, the largest being about $0.32 \mathrm{~mm}$. in length. The shell is, however, not quite spherical and slightly broader than long. This is not apparent when the animal is swimming, for it then appears to be round, the velum being about the same size as the shell (Fig. $4 \mathrm{~m}$ ). The veligers emerge from the parent by means of the upper siphon and swim actively round the wood in which the parent bores. I have never seen them in the plankton. Larvae kept in plunger-jars and bowls metamorphosed into post-larvae, some 
on the wood. The post-larva at the loss of the velum is only slightly larger than the largest inside the parent. Almost directly the velum is lost there is formed a row of fine marginal spines anteriorly, followed quickly by a second (Figs.

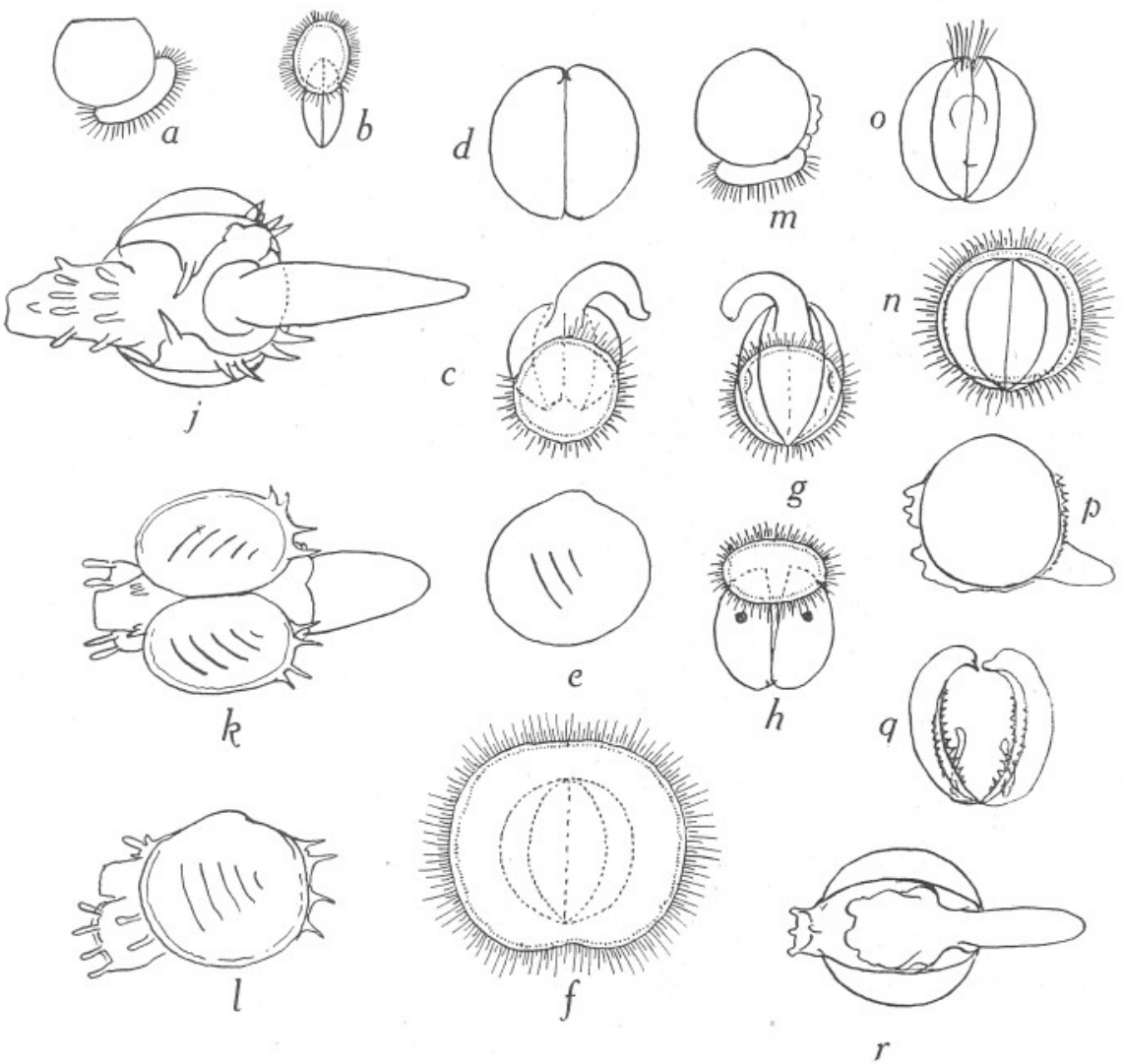

Fig. 4.

$a-b$, Teredo norvegica.

$a, b$, shelled larvae from fertilization, $0.05 \mathrm{~mm}$. long.

$c-l$, almost certainly Teredo norvegica.

$c-f$, later veligers, $0.24-0.38 \mathrm{~mm}$. long; $g, h$, veligers with eyes, probably this species; $j-l$, post-larvae reared from veliger in plunger-jar, shell $0.4 \mathrm{~mm}$. long.

$m-r$, Teredo closely related to Teredo navalis.

$m$, young veliger, $0.24 \mathrm{~mm}$. long; $n, o$, slightly older from parent, $0.32 \mathrm{~mm}$. long; $p-r$, early post-larvae from wood.

$4 n, o, p)$. The siphons with blunt tentacles begin to form, and ventrally there is a central pointed projection in the same position as in the post-larvae of (presumably) T. norvegica, but without a distinct spine. The blades inside the shell are long, reaching nearly half way down the shell. 
The late larvae and post-larvae of this species are strikingly like those of Xylotrya gouldi described by Sigerfoos (I908), and are much more like them than those attributed to Teredo norvegica. Little has been done in the description of post-larval stages of Teredinidae and I have been unable to find in the literature any similar to those described above.

\section{The LaRvae of HiatelLa ARCTICA AND H. GALLICANA}

In the Plymouth Marine Fauna 1931, Hiatella arctica is listed as including rugosa. Winckworth (1932), however, again separates them. The larvae show that they are undoubtedly distinct species, as Odhner (I9I4) has already noted in specimens from Rovigno. Both species are common, $H$. gallicana (=rugosa) always or nearly always boring in stones, $H$. arctica usually free but occasionally found in holes in similar situations. $H$. arctica is not so common as $H$. gallicana and no fertilizations were made from it, but successful fertilizations were made from $H$. gallicana. They breed at different times: $H$. gallicana from autumn to early spring, $H$. arctica in summer. Larvae which developed into $H$. gallicana were present commonly in the plankton from autumn to spring, those of $H$. arctica being common in late summer and early autumn. The best locality for $H$. gallicana is in the red rock dredged from Stoke Point grounds, but the species is also found in the rocks at Rum Bay.

\section{Hiatella arctica (L.) (Figs. $5^{k-q}$ )}

The late larvae of this species are some of the commonest and largest veligers in the plankton, both inside and outside the breakwater at Plymouth, in summer and autumn, beginning about July and continuing to November or December. The late larva ready to metamorphose is about $0.36 \mathrm{~mm}$. in length with a large velum about the length of the shell, the shell having concentric striae round the margin. It is usually a pinkish yellow, being redder towards the margin, but may be almost colourless. The liver is large and conspicuous, a dullish grey, and there are usually three gill slits present. The anterior end of the shell is more pointed than the posterior and the whole shell is somewhat triangular with the longest side ventrally (Figs. $5 k, l$ ). At this size the velum is lost and layers of shell are formed all round, the anterior end being always more acute than the posterior, which is very square. At a length of $0.46 \mathrm{~mm}$. there is one spine at the dorsal posterior end, the siphons have several blunt tentacles and there are five or six gill slits (Figs. $5 m, n)$. At a length of $0.56 \mathrm{~mm}$. it has the same character, but there are two or more posterior dorsal spines (Fig. 50 ), whilst at $0.96 \mathrm{~mm}$. there are two rows of large spines postero-dorsally (Fig. $5 p$ ). A specimen reared in a plungerjar grew to $\mathrm{I} \cdot 44 \mathrm{~mm}$. in length and had another row of spines dorsally (Fig. $5 q$ ). 
This late post-larva is very characteristic and grew many times from veligers in the plunger-jars. Similar specimens are to be found attached to weeds and hydroids in dredgings. The adults are often found in the neighbourhood of rocks.
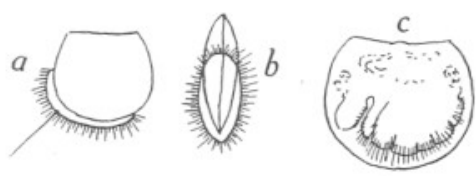

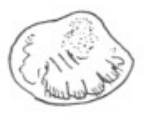

c

g

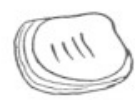

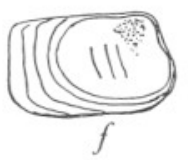
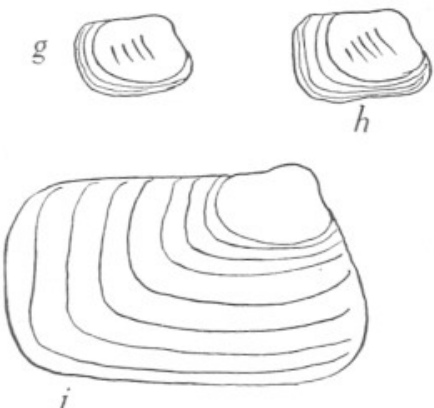

$j$
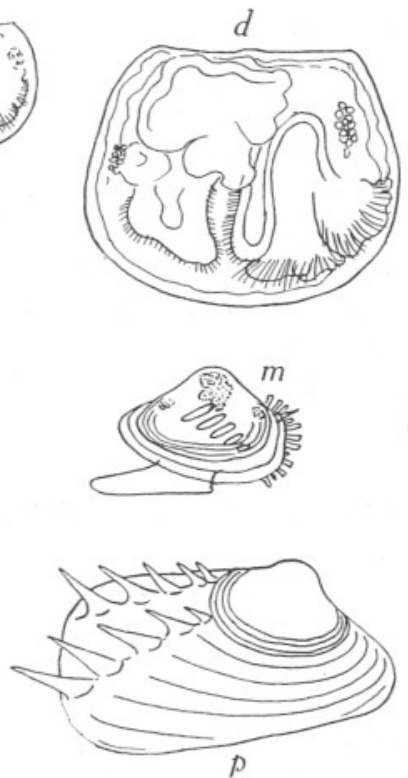

Fig. 5 .

$a-j$, Hiatella gallicana.
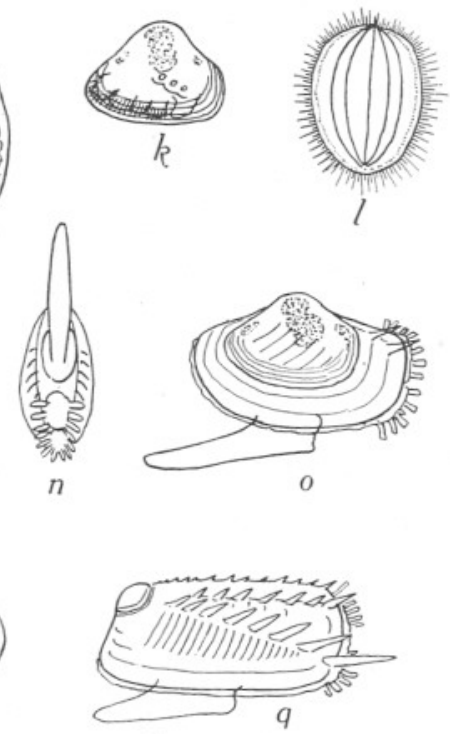

$a, b$, shelled larvae reared from egg, $0.08 \mathrm{~mm}$. long; $c, d$, the same, $0.12 \mathrm{~mm}$. long; $e$, late larva from plankton, $0.32 \mathrm{~mm}$. long; $f$, post-larva, $0.48 \mathrm{~mm}$. long, grown from planktonic veliger in plunger-jar; $g, h$, post-larvae from red rock, $0.38-0.4 \mathrm{~mm}$. long; $j$, young, I mm. long, reared from late veliger in plunger-jar.

\section{$k-q$, Hiatella arctica.}

$k$, $l$, late veliger from plankton, $0.36 \mathrm{~mm}$. long; $m, n$, post-larvae grown from late planktonic veliger in plunger-jar, $0.46 \mathrm{~mm}$. long; $o$, later post-larva grown from late planktonic veliger in plunger-jar, $0.56 \mathrm{~mm}$. long; $p, q$, young reared from late planktonic veliger in plungerjar, $0.96-\mathrm{I} \cdot 44 \mathrm{~mm}$. long.

Hiatella gallicana (Lam.) (Figs. $5 a-j$ )

Successful fertilizations of this species were obtained several times, particularly in winter and early spring. Late larvae from the plankton were reared in plunger-jars and bowls to the post-larval stages and young forms.

The eggs are pinkish although the ovary is usually a pinkish cream colour (Odhner (I9I4) states that the eggs of Hiatella arctica (= Saxicava) are red). The ripe egg is $0.05 \mathrm{~mm}$. across, the free-swimming larva in less than 24 hours is about the same size, the shelled larva very soon after being about $0.08 \mathrm{~mm}$. in length (Figs. $5 a, b$ ) with the velum about two-thirds the length of the 
shell and provided with a large central flagellum. The shell has a straight hinge and the valves are slightly longer than broad.

In eight days the veliger was $0.12 \mathrm{~mm}$. in length with the internal organs forming (Figs. $5 c, d$ ). They did not grow after this and soon died. Late larvae from the plankton are roundish oval, more pointed anteriorly than posteriorly, $0.32 \mathrm{~mm}$. in length (Fig. $5 \mathrm{e}$ ). At this size they lose the velum and put on anterior and posterior growth, especially posterior; usually they are without spines, but occasionally there are slight spines postero-dorsally in the same position as those of $H$. arctica. At a length of $0.48 \mathrm{~mm}$. there are three gill slits in those grown in plunger-jars (Fig. $5 f$ ). In some post-larvae found at the surface of the red rock in which the adult burrows there are four gill slits at a smaller size, the embryonic shell being smaller, and five at a length of $0.4 \mathrm{~mm}$. (Figs. $5 g, h$ ). Young stages reared from veligers in plungerjars grew to I mm. and more, usually still without spines dorsally and of a squarish oblong shape, not so sharply pointed anteriorly as in $H$. arctica (Fig. $5 j$ ).

\section{The Larva and Post-larva of HeTERANOMIA SQUAMULA (L.)}

(Figs. $6 a-f$ )

This is the commonest species of the family Anomiidae at Plymouth. The adults abound on stones and other objects both inside and outside the breakwater, and the larvae are some of the commonest veligers in the plankton. Odhner (19I4) has already described very similar larvae from Rovigno which he regards as Anomia ephippium and mentions another allied species.

Apparently the feature common to all anomiid larvae is the pedal sinus, which is very distinct in Heteranomia. This indentation is the beginning of the hole through which passes the byssus and eventually the plug for attachment. The lower (right) valve is flat, with the indentation; the upper (left) rounded, with a conspicuous umbo and a slight process ventrally which at first fits into the pedal sinus. Fertilizations were made in May and developed into shelled larvae, but the species may be ripe at any time. Specimens watched by $\mathrm{Dr} \mathrm{H}$. B. Moore in a situation in which he knew that the spat fall had occurred in February, were apparently ripe at a length of 5 and $6 \mathrm{~mm}$. in March, active sperm being present and loose red eggs.

The early shelled larva (Fig. $6 a$ ) was $0.05 \mathrm{~mm}$. long with a slightly indented dorsal margin and the velum about two-thirds the length of the shell. No central flagellum was seen in the velum. The larvae from the fertilizations did not live, but the later veligers are very common in the plankton, both inside and outside the breakwater, at almost any time of year but especially in early autumn. The late larva nearly ready to metamorphose is about $0.18 \mathrm{~mm}$. in length, the velum being large, slightly longer than the shell and the foot long and mobile. The larva swims actively shell downwards, the foot helping in the swimming (Figs. $6 b, c$ ). The velum is soon lost, but specimens still 
retaining it with a shell length of $0.2 \mathrm{~mm}$. may be seen (Fig. $6 \mathrm{~d}$ ). The newly metamorphosed larva, from 0.2 to $0.23 \mathrm{~mm}$. in length (Fig. $6 e$ ) crawls on the bottom by means of a very long and contractile foot. At the umbo the early shell may still be seen. Specimens from the plankton which metamorphosed

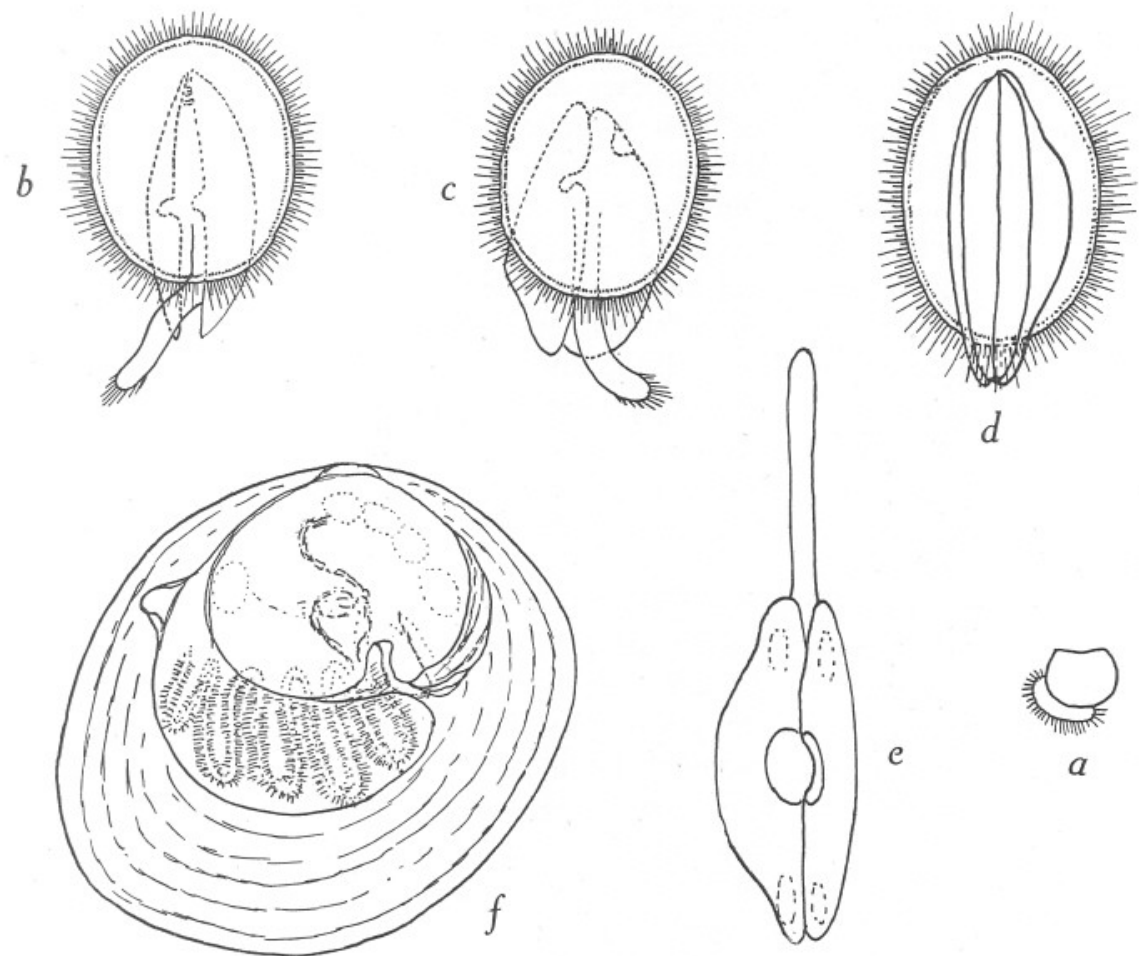

Fig. 6.

Heteranomia squamula.

$a$, early shelled larva from fertilization, $0.05 \mathrm{~mm}$. long; $b, c$, later larvae, from plankton, swimming, $0.18 \mathrm{~mm}$. long; $d$, late veliger, from plankton, ready to metamorphose, $0.2 \mathrm{~mm}$. long; $e$, newly metamorphosed Heteranomia, grown in plunger-jar from planktonic veliger, $0.2 \mathrm{~mm}$. long; $f$, young grown from planktonic veliger in plunger-jar, $0.45 \mathrm{~mm}$. long.

in plunger-jars grew to a large size and settled on the glass. At $0.45 \mathrm{~mm}$. long the pedal sinus growing into the hole for the byssus is well shown (Fig. $6 f$ ).

Another species belonging to the family, which has a much less conspicuous pedal sinus, also occurs in the plankton. This resembles Odhner's specimen from Rovigno and may be Anomia ephippium. 
The Larvae and Post-LaRvae of MYSELLA BIDENTATA AND A Closely RELATED SPECIES

Certain large veligers often occur in the plankton, which when reared in plunger-jars grew into a species of Mysella. It was at first thought that these were $M$. bidentata; but another larva which was much less symmetrical was found which grew up into this species, and in shell gravel near the Eddystone all stages were found. As the first larva certainly belongs to the Montacutidae and the post-larva does not agree with other known species of Mysella or Montacuta it seems that there is a second species of Mysella occurring at Plymouth which is closely related to Mysella bidentata but distinct from it. Both species have the typical median cartilage with the lateral teeth forming a $V$ enclosing it; the mantle is fringed with short processes, the siphons are hardly perceptible, the foot is large and very contractile and the posterior end of the shell is shorter than the anterior. The last character is much more marked both in the larva and post-larva of $M$. bidentata. The larva of the other form, here called Mysella sp., is nearly round, but slightly longer than broad, and the post-larva is oval with the posterior portion only slightly shorter than the anterior.

The larvae are comparable with the large veligers of Kellia suborbicularis (Lebour, 1938) and it is an interesting fact that the adults of both Kellia and of the known species of Mysella are viviparous, giving out their young as shelled larvae and yet attaining a large size before settling down.

Miyazaki (1936a) has described the larvae of Mysella japonica (Yokoyama). This species is also viviparous, the newly freed larvae being $\mathrm{I} 22 \mu$ in length. The largest form reared was $306 \mu$ in length and this is very much like the Plymouth species at that stage. The same worker also reared another mollusc which he found commensal with the crustacean Gebia major. This he names Erycina sp. It is also viviparous, the larva at extrusion being $220 \mu$ in length and beginning to lose the velum at $35 \mathrm{I} \mu$. It is thus seen that all these closely related genera apparently grow to a large size before settling down and that they probably remain a considerable time as planktonic veligers.

\section{Mysella bidentata (Montagu) (Figs. $7 a-c$ )}

Lovén (I848) has described and figured the newly ejected shelled larvae of this species, which are very like those of Kellia but slightly larger. The late larvae in the plankton, occurring chiefly from autumn to spring, are very flat and although nearly circular in outline have the anterior portion longer than the posterior. The velum is about the same size across its longest diameter as the shell. When ready to metamorphose the shell is $0.34 \mathrm{~mm}$. long, with the lateral teeth already formed in a $\mathrm{V}$ and about four gill slits (Fig. $7 a$ ). Slightly larger post-larvae were $0.4 \mathrm{~mm}$. long and more oblique (Fig. $7 \mathrm{~b}$ ). Young specimens about $0.5 \mathrm{~mm}$. long had the adult form with the anterior 
end very much elongated. At a length of about $0.80 \mathrm{~mm}$. the siphon and mantle processes were formed, and the teeth and cartilage were typical (Fig. $7 \mathrm{c}$ ).

\section{Mysella sp. (Figs. $7 d-g$ )}

Adults of this species have not yet been found, but young forms grown up from the plankton in plunger-jars show decided differences from the preceding species, the veliger differing much in form. Veligers from about 0.2 to

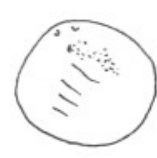

$a$
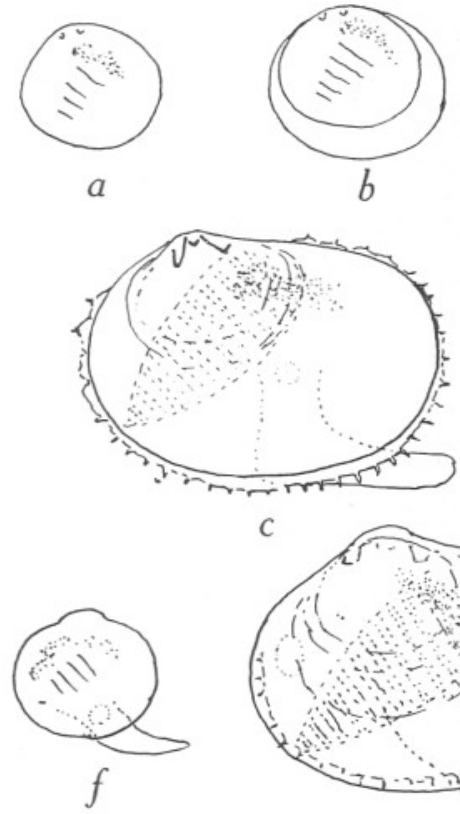

$c$

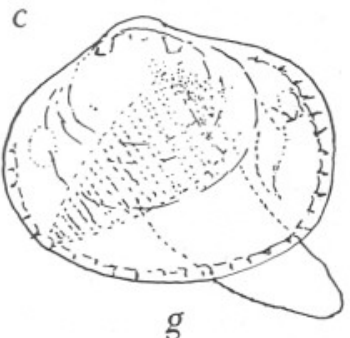

Fig. 7 .

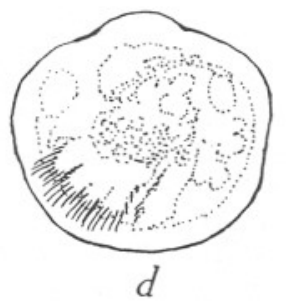

$a-c$, Mysella bidentata.

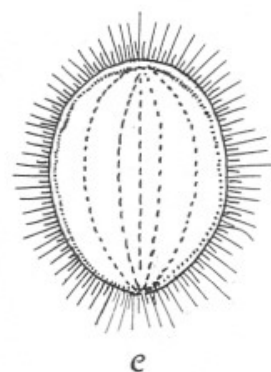

e

$$
d-g, \text { Mysella sp. }
$$

$a$, late veliger from plankton, $0.34 \mathrm{~mm}$. long; $b$, post-larva from shell gravel, $0.4 \mathrm{~mm}$. long; $c$, young from shell gravel, $0.82 \mathrm{~mm}$. long.

$d$, e, veliger of Mysella sp. from plankton, $0.2 \mathrm{~mm}$. long; $f$, newly metamorphosed form reared from planktonic veliger in plunger-jar, $0.32 \mathrm{~mm}$. long; $g$, young reared from planktonic veliger in plunger-jar, $0.80 \mathrm{~mm}$. long.

$0.32 \mathrm{~mm}$. across are very common in the plankton, especially in late summer and autumn, but they may also be found in spring. The velum is large and oval, reaching as far as the shell length (Figs. $7 d, e)$. At about $0.32 \mathrm{~mm}$. the larva loses the velum (Fig. $7 f$ ). The shell is very round in outline, the younger specimen being slightly longer than broad and at the time of metamorphosis both anterior and posterior ends are almost equal. Grown in plunger-jars these post-larvae grew into oval young with the posterior end rather shorter than the anterior and the mantle edged with fine processes (Fig. $7 g$ ). The cartilage 
is well formed as well as the lateral teeth, the latter being blunter than those of $M$. bidentata and not forming such a distinct $\mathrm{V}$. The foot is more pointed than in that species.

It was noticed in specimens of Montacuta substriata (Montagu) that the embryonic shell, visible in the adults, measured about $0.20 \mathrm{~mm}$. in length, again showing a probable tendency to a large veliger in a viviparous form.

\section{REFERENCES}

Drew, G. A., I90I. The life history of Nucula delphinodonta (Mighels). Quart. Fourn. Micr. Sci., N.S., Vol. XLIV, pp. 313-9I.

HaAs, F., I929, I937. Klassen und Ordnungen des Tierreichs. Bivalvia, I, pp. I-984; II, pp. I-208.

KäNDLER, R., I926. Muschellarven aus dem Helgolander Plankton. Wiss. Meeresuntersuch., Bd. xvi (5), Abt. Helgoland, pp. I-8.

Lebour, M. V., I921. The food of young clupeoids. Fourn. Mar. Biol. Assoc., Vol. xII, pp. $45^{8-67 .}$

— I922. The food of plankton organisms. Fourn. Mar. Biol. Assoc., Vol. xiI, pp. $644-77$.

— 1927. Studies of the Plymouth Brachyura. I. The rearing of crabs in captivity with a description of the larval stages of Inachus Dorsettensis, Macropodia longirostris and Maia squinado. Fourn. Mar. Biol. Assoc., Vol. xIV, pp. 795-8I4.

- 1937. Larval and post-larval Lima from Plymouth. Fourn. Mar. Biol. Assoc., Vol. xxI, 2, pp. 705-IO.

— I938. The life history of Kellia suborbicularis. Fourn. Mar. Biol. Assoc., Vol. Xxir, pp. 447-5I.

LovéN, G., 1848. Beiträge zur Kenntniśs der Entwicklung der Mollusca. Acephala Lamellibranchia. Abhandl. K. Schwed. Ak. Wiss. 1848. (Republished in 1879 at Stockholm with additional notes, pp. I-39.)

Matthews, A., I9I3. Notes on the development of Mytilus edulis and Alcyonium digitatum in the Plymouth Laboratory. Fourn. Mar. Biol. Assoc., Vol. Ix, pp. 557-60.

MrYAZAKI, I., 1935. On the development of some marine bivalves, with special reference to the shelled larvae. Fourn. Imp. Fisher. Inst., Vol. xxxI, No. I, pp. I-IO.

_ I $1936 a$. On the development of some marine bivalves, with special reference to the shelled larvae. II. Fourn. Imper. Fish. Inst., Vol. xxxI, No. 2, pp. 35-4I.

- I936b. On the development of bivalves belonging to the genus Corbicula. Bull. Fap. Soc. Sci. Fisheries, Vol. 5, No. 4, pp. 249-54.

ODHneR, N. H., I9I4. Notizen über die Faune der Adria bei Rovigno. Beiträge zur Kenntnis der Marinen Molluskenfauna von Rovigno in Istrien. Zool. Anz., Bd. XLIV, Heft 2, pp. I45-70.

Pelseneer, P., I926. Notes d'embryologie malacologique. Ponte et développement de Cypraea europaea, Triforis perversa et Lucina lactea. Bull. Biol. France et Belg., Tome Lx, pp. 88-II2.

Sigerfoos, C. P., I908. Natural history, organization and late development of the Teredinidae or Ship-worms. Bull. Bur. Fish. Washington, Vol. xxvir, pp. I9I-23I.

Thorson, G., 1935. Biologische Studien über die Lamellibranchier Modiolaria discors L. und Modiolaria nigra Gray in Ostgrönland. Zool. Anz., Bd. CXI, Heft II-I2, pp. 297-304.

Winckworth, R., I932. The British Marine Mollusca. fourn. Conch., Vol. xIx, No. 7, pp. 2II-52. 